\title{
Analisa Ergonomis Pemanfaatan Meja dan Sofa dari Limbah Ban Mobil
}

\author{
Diana Chandra Dewi \\ Teknik Industri \\ Correspondence Email: dianachandradewi.dc@gmail.com
}

\begin{abstract}
Abstrak. Semakin bertambahnya jumlah kendaraan maka semakin banyak permasalahan yang ditimbulkan, misalnya pencemaran udara dari aktivitas mesin yang berjalan dan banyaknya limbah ban bekas dari kendaraan tersebut. Limbah ban bekas dapat menimbulkan berbagai permasalahan yang serius jika tidak ditangani dengan tepat. Ban bekas merupakan limbah yang berbahaya bagi lingkungan. Limbah jenis ini akan sulit terurai oleh bakteri pengurai, hal ini akan sangat membahayakan lingkungan. Penelitian ini bertujuan untuk menganalisa meja dan sofa dengan memanfaatkan limbah ban mobil sebagai bahan baku utama dan agar dapat memenuhi aspek ENASE sehingga meja dan sofa yang dibuat dapat dikatakan ergonomis. Metode yang digunakan dalam penelitian ini antara lain metode kualitatif dan kuantitatif. Teknik pengolahan data dalam penelitian ini menggunakan uji perbandingan dan uji regresi linier berganda (ANOVA) untuk memastikan data relevan. Pada uji perbandingan yang telah dilakukan terdapat perbedaan diantara semua variabel sebelum dan sesudah dan pada uji regresi linier berganda (ANOVA) yang telah dilakukan tidak ada pengaruh antara variabel dependen dan variabel independen.
\end{abstract}

Kata kunci: Ban bekas, Ergonomis, Limbah, Meja dan sofa, Enase

\begin{abstract}
The more the number of vehicles increases, the more problems that arise, for example air pollution from running engine activities and the amount of used tire waste from the vehicle. Waste from used tires can cause various serious problems if not handled properly. Used tires are waste that is harmful to the environment. This type of waste will be difficult to decompose by decomposing bacteria, this will be very dangerous for the environment. This study aims to analyze tables and sofas by utilizing car tire waste as the main raw material and in order to fulfill the ENASE aspect so that the tables and sofas made can be said to be ergonomic. The methods used in this study include qualitative and quantitative methods. Data processing techniques in this study used a comparison test and multiple linear regression test (ANOVA) to ensure relevant data. In the comparison test that has been done there are differences between all variables before and after and in the multiple linear regression test (ANOVA) that have been carried out there is no influence between the dependent variable and the independent variable.
\end{abstract}

Keywords: Ergonomics, Tables and sofas, used tires, Waste, Enase

\section{PENDAHULUAN}

Limbah ban bekas mobil akan sulit terurai oleh bakteri pengurai, hal ini akan sangat membahayakan lingkungan. Berdasarkan sifat dari limbah ban tersebut, terdapat produk yang bisa diciptakan dengan memanfaatkan limbah ban bekas yaitu meja dan sofa yang dapat digunakan untuk duduk dan bersantai. Beberapa keunggulan produk kursi dan meja berbahan dasar ban bekas dibandingkan dengan meja dan sofa yang lain, diantaranya:

1. Aman untuk digunakan karena sifatnya yang elastis dan fleksibel.

2. Bahan baku dapat diperoleh dengan harga yang relatif murah.

3. Lebih tahan lama dibandingkan dengan meja dan sofa yang terbuat dari kayu yang di lapisi busa, wol, ataupun karet saja.

Hendri dkk (2013) dalam penelitian yang berjudul Kurma Mini BABE (Kursi dan Meja Mini Berbahan dasar Ban bekas) dengan Seni Motif Aneka Kartun Anak oleh). Menggunakan ban bekas mobil sebagai media utama untuk digunakan sebagai kursi dan meja yang di buat untuk anak-anak TK, PAUD, dan Play Group, maka dari itu kursi dan meja mini yang dibuat dengan banyak warna dan motif yang digunakan, Falaah dkk, (2013) dalam penelitian yang berjudul Pemanfaatan hasil Pirolisis Limbah ban Bekas sebagai bahan Pelunak untuk pembuatan barang jadi Karet, juga memanfaatkan limbah ban sebagai media utama untuk bahan pelunak bahan jadi karet.

Sedangkan perancangan yang dilakukan oleh Ramadhan (2019) dengan judul Perancangan Meja dan Sofa yang Ergonomis dari Limbah Ban Mobil dengan Pendekatan Anthropometri tersebut memanfaatkan ban bekas mobil sebagai media utama untuk pembuatan meja dan sofa. Nantinya hasil rancangan meja dan sofa yang dibuat oleh Ramadhan (2019) akan ditempatkan pada ruang tunggu (lobby) Kampus dengan desain yang lebih elegan dan masih memperlihatkan ban mobil sebagai bahan baku sehingga tampak keunikannya.

Dengan uraian diatas maka akan dilakukan penelitian Analisa Ergonomis pemanfaatan meja dan sofa dari ban bekas mobil yang telah dibuat oleh Ramadhan (2019), agar dapat diketahui tingkat kenyamanannya menggunakan aspek ENASE sebagai parameter utama dengan pendekatan Ergonomis.

\section{Defenisi Ergonomi}

Menurut Nurmianto (2005), berdasarkan Internasional Ergonomics Association, istilah 
"ergonomi" berasal dari bahasa latin yaitu ergo (kerja) dan nomos (hukum alam) dan dapat didefinisikan sebagai studi tentang aspek-aspek manusia dalam lingkungan kerjanya yang di tinjau secara anotomi, fisiologi, psikologi, engineering, manajemen dan desain/perancangan.

\section{Defenisi Antropometri}

Antropometri merupakan bagian dari ergonomi yang secara khusus mempelajari ukuran tubuh yang meliputi dimensi linear, serta, isi dan juga meliputi daerah ukuran, kekuatan, kecepatan dan aspek lain dari gerakan tubuh. Secara devinitif antropometri dapat dinyatakan sebagai suatu studi yang berkaitan dengan ukuran dimensi tubuh manusia meliputi daerah ukuran, kekuatan, kecepatan dan aspek lain dari gerakan tubuh manusia, (Stevenson, 1989) dalam buku Ergonomi.

\section{ENASE (Efektif, Nyaman, Aman, Sehat dan Efisien)}

\section{Efektif}

Menurut Steers (1980), efektifitas atau yang berasal dari efektif yaitu suatu pekerjaan dikatakan efektif jika suatu pekerjaan dapat menghasilkan salah satu unit yang merupakan keluaran (output). Dalam penelitian ini nyaman yang dimaksud adalah respon dari pengguna produk dapat memberikan rasa nyaman pada saat digunakan, sehingga produk tersebut dapat digunakan setiap waktu.

2. Nyaman

Menurut Kolcaba (2003) menjelaskan bahwa kenyamaan sebagai suatu keadaan telah terpenuhinya kebutuhan dasar manusia yang bersifat individual dan holistik. Dalam penelitian ini aman yang dimaksud adalah memaksimalkan proses pembuatan agar dapat menghasilkan produk yang kuat dan tahan lama untuk digunakan.

\section{Aman}

Keamanan adalah keadaan bebas dari bahaya. Istilah ini bisa digunakan dengan kata lain sebagai hubungan kepada kejahatan, segala bentuk kecelakaan, dan lainlain. Dalam penelitian ini aman yang dimaksud adalah memaksimalkan proses pembuatan agar dapat menghasilkan produk yang kuat dan tahan lama untuk digunakan.

4. Sehat

Pengertian kesehatan menurut WHO (World Health Organization) adalah suatu keseimbangan ekologi yang harus ada diantara manusia dan lingkungan agar dapat menjamin keadaan sehat manusia. Dalam penelitian ini sehat yang dimaksud berasal dari bahan-bahan yang digunakan untuk pembuatan produk sehingga produk yang dibuat dapat digunakan tanpa menimbulkan efek samping yang negatif.

5. Efisien

Menurut Maulana (1997) efisiensi diartikan sebagakemampuan suatu unit usaha untuk mencapai tujuan yang diinginkan, efisiensi selalu dikaitkan dengan tujuan organisasi yang harus dicapai oleh perusahaan, dalam penelitian ini efisien yang dimaksud adalah dapat memanfaatkan limbah ban mobil menjadi produk yang memiliki nilai ekonomi yang lebih tinggi.

\section{METODE}

Jenis penelitian yang digunakan dalam menganalisa meja dan sofa berbahan dasar limbah ban mobil ini adalah metode penelitian one group pretest dan posttest, kualitatif dan kuantitaf. Adapun waktu pelaksanaan penelitian mulai Maret 2018 sampai Januari 2019. Tempat pelaksanaan penelitian dilakukan di STITEKNAS Jambi yang beralamat di Jl. Kapten Patimura No.100 (eks. Gedung transito) Kel. Rawasari, Kec. Alam Barajo, Kota Jambi, Provinsi Jambi, Indonesia. Objek penelitian adalah Individu sebagai responden sebanyak 30 orang mahasiswa STITEKNAS Jambi yang akan menguji meja dan sofa yang telah dibuat.

\section{Sumber Data}

a. Dalam penelitian ini data primer berupa biodata responden, data antropometri berupa dimensi tubuh yang diukur meliputi Tinggi popliteal (Tpo), Lebar pinggul (Lp), Tinggi bahu duduk (Tbd), Jangkauan horizontal duduk (Jhd), dan kuesioner ENASE meja dan sofa.

b. Dalam penelitian ini data sekunder yang digunakan antara lain, jurnal yang berkaitan dengan penelitian ini, buku referensi untuk menemukan model yang sesuai dengan rancangan yang diinginkan, foto-foto meja dan sofa yang telah dibuat, internet, dan skripsi yang berkaitan dengan penelitian ini.

\section{Pengujian Data Kuesioner}

Pengujian kuesioner yang telah diberi pembobotan nilai skala likert adalah pengujian yang dilakukan untuk memastikan kuesioner layak digunakan,

a. Uji Validitas

Menurut Ghozali (2009) menyatakan bahwa uji validitas digunakan untuk mengukur sah, atau valid tidaknya suatu kuesioner. Kuesioner dikatakan valid jika pertanyaan pada kuesioner mampu untuk mengungkapkan sesuatu yang akan diukur oleh kuesioner tersebut.

b. Uji Reliabilitas

Menurut Ghozali (2009), reliabilitas adalah alat untuk mengukur suatu kuesioner yang merupakan indikator dari peubah atau konstruk. Suatu kuesioner dikatakan reliabel atau handal jika jawaban seseorang terhadap pernyataan adalah konsisten atau stabil dari waktu ke waktu.

c. Uji perbandingan

Menurut Misbahudin (2013) Pengertian Analisis komparatif atau analisis komparasi atau uji beda adalah bentuk analisis variabel (data) untuk 
mengetahui perbedaan diantara dua kelompok data (variabel) atau lebih. Analisis komparatif atau uji perbedaan ini sering disebut uji signifikansi.

d. Regresi linier berganda (ANOVA)

Menurut Sugiyono (2014) Analisis regresi linier berganda bermaksud meramalkan bagaimana keadaan (naik turunnya) variabel dependen (kriterium), bila dua atau lebih variabel independen sebagai faktor prediator dimanipulasi (dinaik turunkan nilainya). Jadi analisis regresi berganda akan dilakukan bila jumlah variabel independennya minimal 2 variabel. Menurut Ghozali (2009) Analysis of variance atau ANOVA merupakan salah satu uji parametrik yang berfungsi untuk membedakan nilai rata-rata lebih dari dua kelompok data dengan cara membandingkan variasinya.

\section{Kerangka Penelitian}

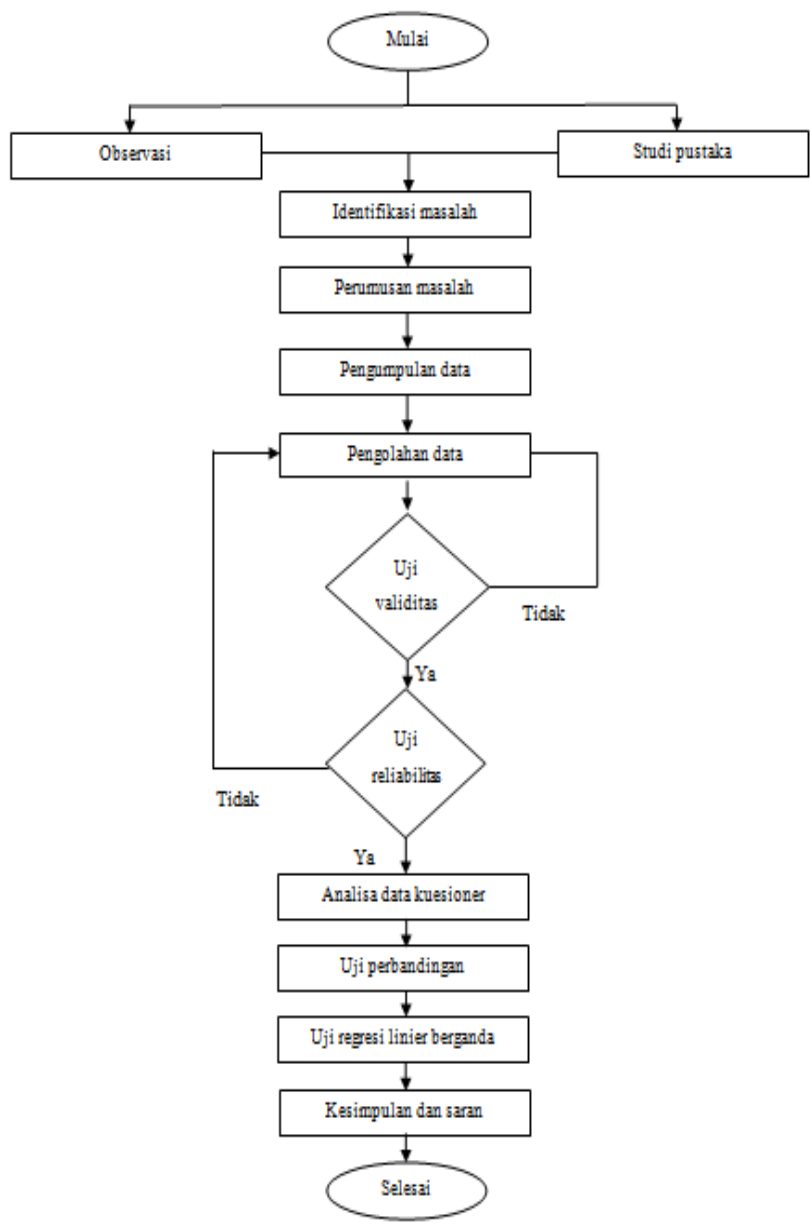

\section{HASIL DAN PEMBAHASAN}

Perbandingan Ukuran Meja Dan Sofa Biasa Dengan Meja Dan Sofa Bahan Dasar Limbah Ban Mobil

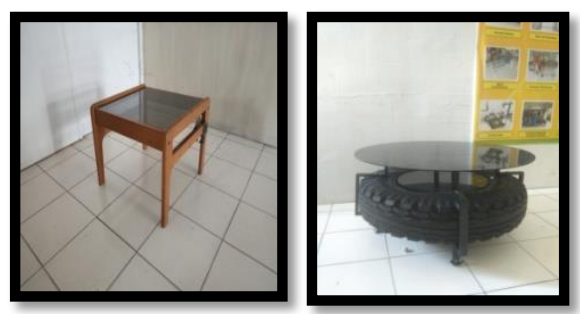

\begin{tabular}{|c|c|c|}
\hline $\begin{array}{c}\text { Variabel } \\
\text { pembanding }\end{array}$ & Meja biasa & $\begin{array}{c}\text { Meja limbah ban } \\
\text { mobil }\end{array}$ \\
\hline Tinggi & $38 \mathrm{~cm}$ & $50 \mathrm{~cm}$ \\
\hline Luas permukaan & $53 \mathrm{~cm}$ & $86.53 \mathrm{~cm}$ \\
\hline Bentuk permukaan & Persegi & Bulat \\
\hline Bahan utama & Kayu & Ban mobil \\
\hline
\end{tabular}

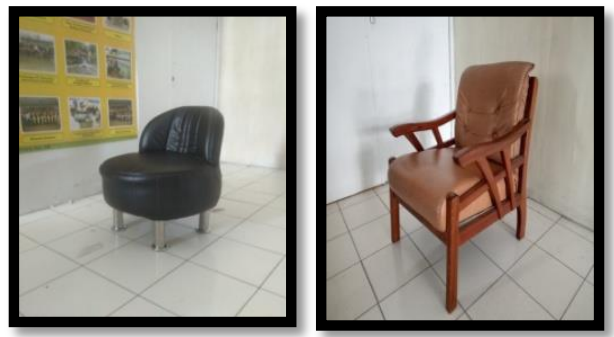

\begin{tabular}{|c|c|c|}
\hline $\begin{array}{c}\text { Variabel } \\
\text { pembanding }\end{array}$ & Sofa biasa & $\begin{array}{c}\text { Sofa limbah } \\
\text { ban mobil }\end{array}$ \\
\hline Tinggi sofa & $38 \mathrm{~cm}$ & $44.51 \mathrm{~cm}$ \\
\hline Tinggi sandaran & $42 \mathrm{~cm}$ & $55.16 \mathrm{~cm}$ \\
\hline Lebar sandaran & $53 \mathrm{~cm}$ & $47 \mathrm{~cm}$ \\
\hline Luas permukaan & $53 \mathrm{~cm}$ & $37.59 \mathrm{~cm}$ \\
\hline Bentuk permukaan & Persegi & Bulat \\
\hline Bahan utama & Kayu & Ban mobil \\
\hline
\end{tabular}

\section{Prosentase Data Kuesioner Meja Dan Sofa Biasa}

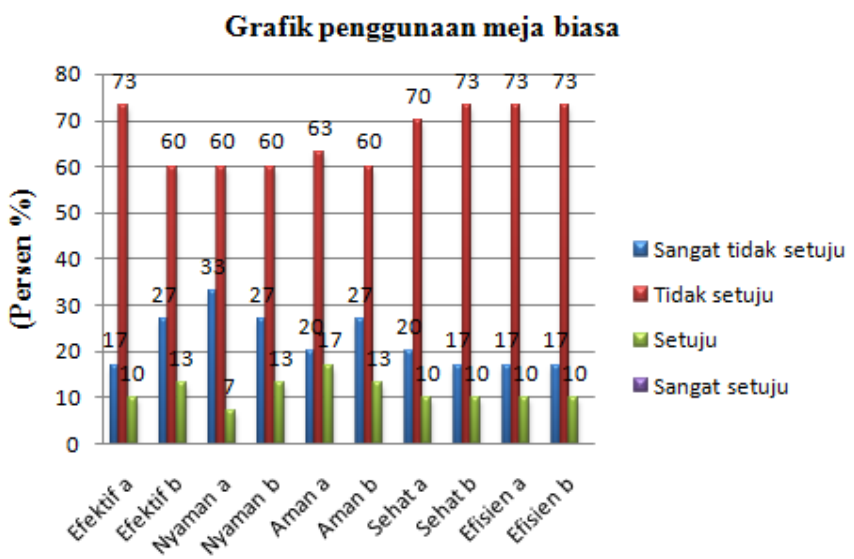

Pada grafik penggunaan meja biasa diatas responden cenderung memilih kotak berwarana merah dan biru yang artinya tidak setuju dan sangat tidak setuju, dibandingkan kotak berwarna hijau yang lebih sedikit dipilih yaitu setuju, artinya meja biasa tersebut belum memenuhi aspek ENASE sehingga meja biasa tersebut belum ergonomis. 
Grafik penggunaan sofa biasa

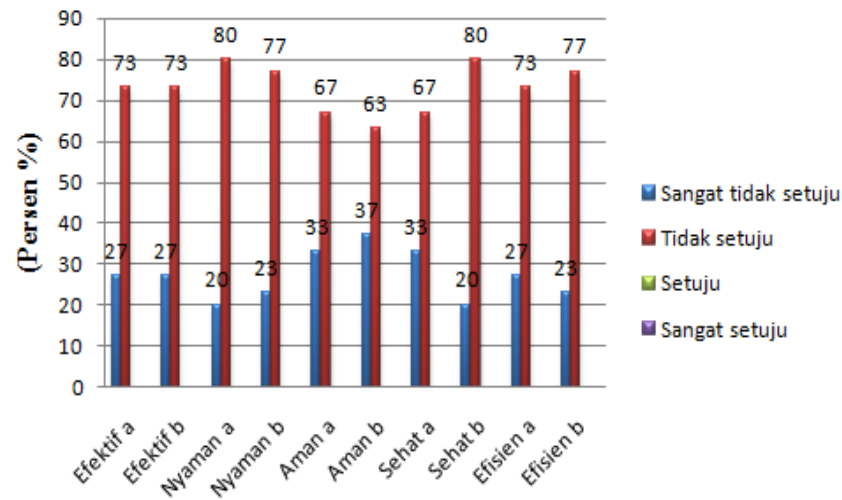

Pada grafik penggunaan sofa biasa diatas responden cenderung memilih kotak berwarana merah dan biru yang artinya tidak setuju dan dan sangat tidak setuju, dan tidak ada satu pu responden yang memilih kotak berwarna hijau ataupun ungu yang artinya setuju dan sangat setuju, artinya sofa biasa tersebut belum memenuhi aspek ENASE sehingga sofa biasa tersebut belum ergonomis.

\section{Prosentase data kuesioner meja dan sofa bahan dasar limbah ban mobil}

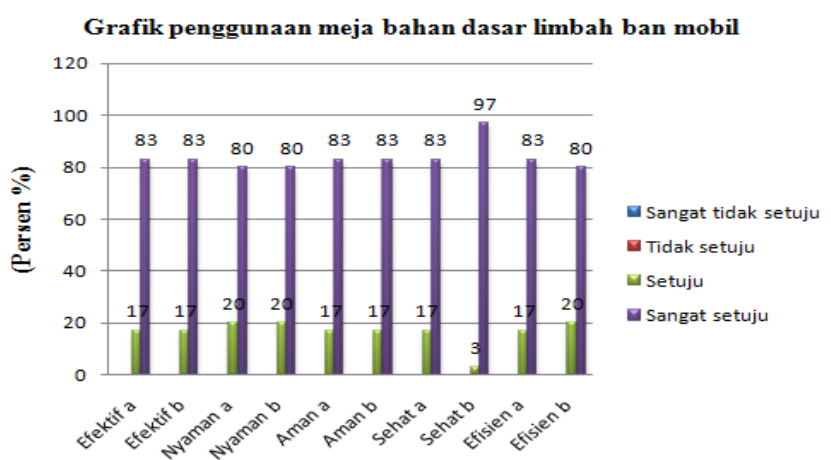

Pada grafik penggunaan meja bahan dasar limbah ban mobil diatas responden cenderung memilih kotak berwarana ungu dan hijau yang artinya sangat setuju dan setuju, artinya meja bahan dasar limbah ban mobil diatas telah memenuhi aspek ENASE sehingga meja bahan dasar limbah ban mobil tersebut sudah ergonomis.

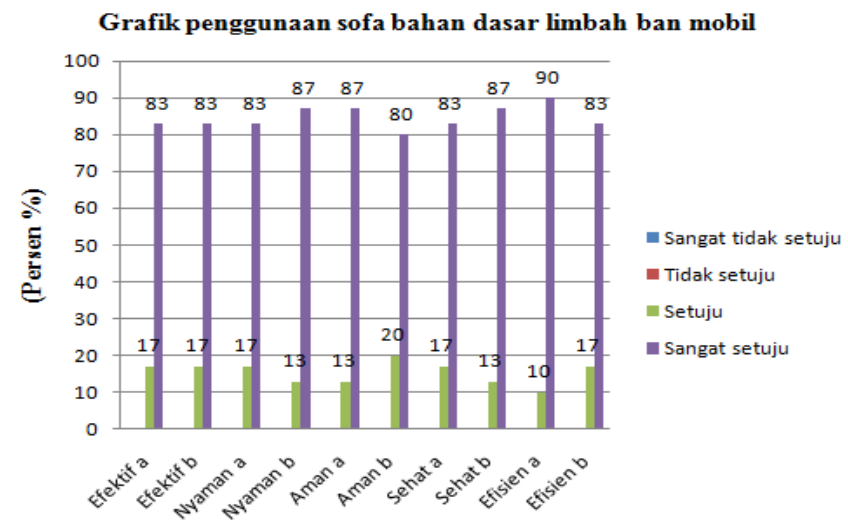

Pada grafik penggunaan sofa bahan dasar limbah ban mobil diatas responden cenderung memilih kotak berwarana ungu dan hijau yang artinya sangat setuju dan setuju, artinya sofa bahan dasar limbah ban mobil diatas telah memenuhi aspek ENASE sehingga sofa bahan dasar limbah ban mobil tersebut sudah ergonomis.

\section{Data validitas}

\begin{tabular}{|c|c|c|c|c|}
\hline Variabel & $\begin{array}{c}\text { Meja } \\
\text { Biasa }\end{array}$ & $\begin{array}{c}\text { Sofa } \\
\text { Biasa }\end{array}$ & $\begin{array}{c}\text { Meja Ban } \\
\text { Mobil }\end{array}$ & $\begin{array}{c}\text { Sofa } \\
\text { Ban } \\
\text { Mobil }\end{array}$ \\
\hline $\begin{array}{c}\text { Pertanyaan } \\
\text { 1a }\end{array}$ & $\begin{array}{c}\text { Tidak } \\
\text { Valid }\end{array}$ & Valid & Valid & $\begin{array}{c}\text { Tidak } \\
\text { Valid }\end{array}$ \\
\hline $\begin{array}{c}\text { Pertanyaan } \\
\text { 1b }\end{array}$ & Valid & Valid & Valid & Valid \\
\hline $\begin{array}{c}\text { Pertanyaan } \\
\text { 2a }\end{array}$ & $\begin{array}{c}\text { Tidak } \\
\text { Valid }\end{array}$ & $\begin{array}{c}\text { Tidak } \\
\text { Valid }\end{array}$ & Valid & Valid \\
\hline $\begin{array}{c}\text { Pertanyaan } \\
\text { 2b }\end{array}$ & Valid & $\begin{array}{c}\text { Tidak } \\
\text { Valid }\end{array}$ & $\begin{array}{c}\text { Tidak } \\
\text { Valid }\end{array}$ & Valid \\
\hline $\begin{array}{c}\text { Pertanyaan } \\
\text { 3a }\end{array}$ & Valid & $\begin{array}{c}\text { Tidak } \\
\text { Valid }\end{array}$ & Valid & $\begin{array}{c}\text { Tidak } \\
\text { Valid }\end{array}$ \\
\hline $\begin{array}{c}\text { Pertanyaan } \\
\text { 3b }\end{array}$ & $\begin{array}{c}\text { Tidak } \\
\text { Valid }\end{array}$ & $\begin{array}{c}\text { Tidak } \\
\text { Valid }\end{array}$ & $\begin{array}{c}\text { Tidak } \\
\text { Valid }\end{array}$ & Valid \\
\hline $\begin{array}{c}\text { Pertanyaan } \\
\text { 4a }\end{array}$ & Valid & $\begin{array}{c}\text { Tidak } \\
\text { Valid }\end{array}$ & $\begin{array}{c}\text { Tidak } \\
\text { Valid }\end{array}$ & $\begin{array}{c}\text { Tidak } \\
\text { Valid }\end{array}$ \\
\hline $\begin{array}{c}\text { Pertanyaan } \\
\text { 4b }\end{array}$ & Valid & Valid & Valid & $\begin{array}{c}\text { Tidak } \\
\text { Valid }\end{array}$ \\
\hline $\begin{array}{c}\text { Pertanyaan } \\
\text { 5a }\end{array}$ & $\begin{array}{c}\text { Tidak } \\
\text { Valid }\end{array}$ & Valid & Valid & Valid \\
\hline $\begin{array}{c}\text { Pertanyaan } \\
\text { 5b }\end{array}$ & Valid & Valid & $\begin{array}{c}\text { Tidak } \\
\text { Valid }\end{array}$ & Valid \\
\hline
\end{tabular}

Pada tabel diatas dapat dilihat bahwa pada semua objek penelitian yang telah dilakukan terdapat 23 data yang dinyatakan valid (warna biru), data yang dinyatakan tidak valid dihapuskan agar dapat dilanjutkan ke tahap uji reliabilitas.

\section{Data reliabilitas}

\begin{tabular}{|c|c|}
\hline Variabel & Keterangan \\
\hline Meja Biasa & Reliabel \\
\hline Sofa Biasa & Reliabel \\
\hline Meja Ban Mobil & Reliabel \\
\hline Sofa Ban Mobil & Reliabel \\
\hline
\end{tabular}

Pada tabel diatas dapat dilihat bahwa hasil dari uji reliabilitas yang telah dilakukan terhadap semua objek penelitian dapat dinyatakan semua data reliabel.

\section{Analisa Perbandingan Meja Biasa Dengan Meja Bahan Dasar Limbah Ban Mobil}




\section{Paired Samples Test}

\begin{tabular}{|c|c|c|c|c|c|c|c|c|c|}
\hline & & & & Paired Differ & nces & & $t$ & $D f$ & Sig. (2- \\
\hline & & Mean & $\begin{array}{c}\text { Std. } \\
\text { Deviati } \\
\text { on }\end{array}$ & $\begin{array}{c}\text { Std. Error } \\
\text { Mean }\end{array}$ & $\begin{array}{r}95 \% \text { Confi } \\
\text { Interval } \\
\text { Differe }\end{array}$ & $\begin{array}{l}\text { dence } \\
\text { f the } \\
\text { ce }\end{array}$ & & & tailed) \\
\hline & & & & & Lower & Upper & & & \\
\hline $\begin{array}{l}\text { Pair } \\
1\end{array}$ & $\begin{array}{l}\text { p1bsb. } \\
\text { p1bsd }\end{array}$ & -1.967 & .669 & .122 & -2.216 & -1.717 & -16.109 & 29 & .000 \\
\hline $\begin{array}{l}\text { Pair } \\
2\end{array}$ & $\begin{array}{l}\text { p3asb. } \\
\text { p3asd }\end{array}$ & -1.867 & .819 & .150 & -2.173 & -1.561 & -12.479 & 29 & .000 \\
\hline $\begin{array}{l:}\text { Pair } \\
3\end{array}$ & $\begin{array}{l}\text { p4bsb- } \\
\text { p4bsd }\end{array}$ & -2.033 & .556 & .102 & -2.241 & -1.826 & -20.029 & 29 & .000 \\
\hline
\end{tabular}

Sumber : Hasil perhitungan menggunakan SPSS

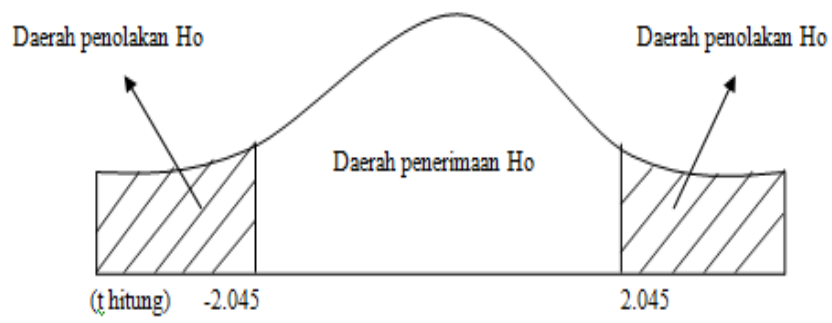

Jika :

a. $t_{\text {hitung }}<t_{\text {tabel }}$ maka Ho diterima

b. $t_{\text {hitung }}>t_{\text {tabel }}$ maka Ha diterima

Karena nilai dari hasil perhitungan didapatlah nilai sebagai berikut:

a. Variabel $1=-16.109>-2.045$

b. Variabel $2=-12.479>-2.045$

c. Variabel $3=-20.029>-2.045$

Pada uraian diatas dapat dilihat bahwa $t_{\text {hitung }}$ lebih besar daripada $t_{\text {tabel}}$, pada grafik diatas dapat dilihat bahwa thitung berada pada daerah penolakan Ho, artinya Ha diterima artinya terjadi perbedaan dalam penggunaan meja biasa dan meja bahan dasar limbah ban mobil.

\section{Analisa Perbandingan Sofa Biasa Dengan Sofa Bahan Dasar Limbah Ban Mobil}

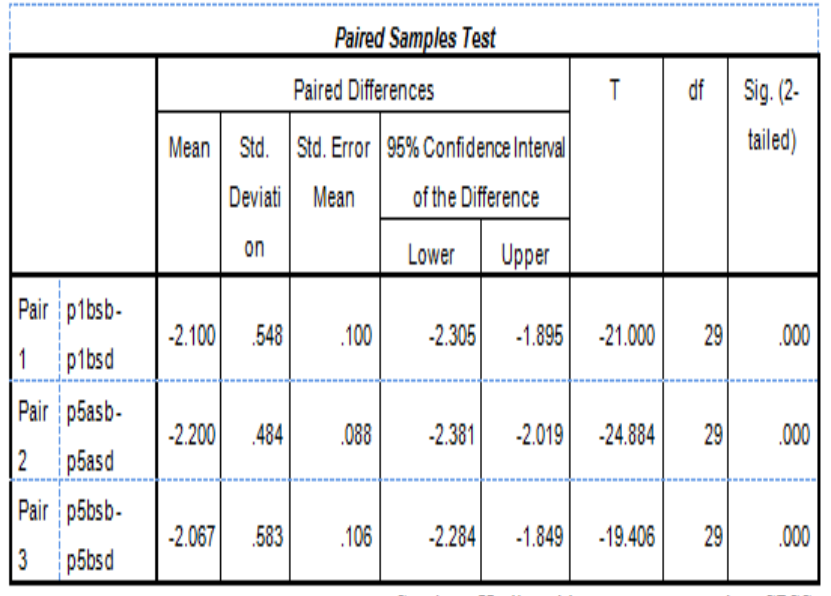

Sumber : Hasil perhitungan menggunakan SPSS

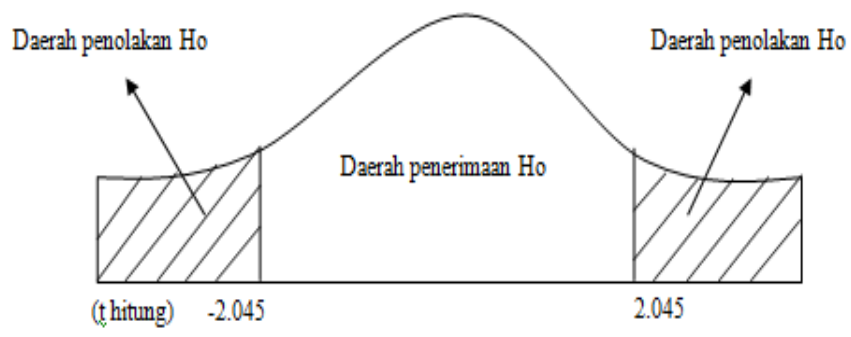

Jika :

a. $t_{\text {hitung }}<\mathrm{t}_{\text {tabel }}$ maka Ho diterima

b. $t_{\text {hitung }}>t_{\text {tabel }}$ maka Ha diterima

Karena nilai dari hasil perhitungan didapatlah nilai sebagai berikut :

a. Variabel $1=-16.109>-2.045$

b. Variabel $2=-12.479>-2.045$

c. Variabel $3=-20.029>-2.045$

Pada uraian diatas dapat dilihat bahwa $t_{\text {hitung }}$ berada pada daerah penolakan Ho, artinya Ha diterima artinya terjadi perbedaan dalam penggunaan sofa biasa dan sofa bahan dasar limbah ban mobil.

\section{Uji regresi linier berganda meja biasa}

\begin{tabular}{|c|c|c|c|c|c|c|}
\hline \multicolumn{7}{|c|}{ ANOVA $^{2}$} \\
\hline Mo & & Sum of Squares & $\mathrm{Df}$ & Mean Square & $\mathrm{F}$ & Sig. \\
\hline \multirow{3}{*}{1} & Regression & .531 & 2 & .265 & .655 & $.527^{\circ}$ \\
\hline & Residual & 10.936 & 27 & .405 & & \\
\hline & Total & 11.467 & 29 & & & \\
\hline
\end{tabular}

Sumber: Hasil perhitungan menggunakan SPSS Coefficients $^{2}$

\begin{tabular}{|c|c|c|c|c|c|c|}
\hline \multirow{2}{*}{\multicolumn{2}{|c|}{ Model }} & \multicolumn{2}{|c|}{ Unstandardized Coefficients } & \multirow{2}{*}{$\begin{array}{c}\begin{array}{c}\text { Standardized } \\
\text { Coefficients }\end{array} \\
\text { Beta }\end{array}$} & \multirow[t]{2}{*}{ T } & \multirow[t]{2}{*}{ Sig. } \\
\hline & & $B$ & Std. Error & & & \\
\hline \multirow{3}{*}{1} & (Constant) & 1.474 & .511 & & 2.883 & .008 \\
\hline & Aman & -.005 & .203 & -.005 & -.026 & .979 \\
\hline & Sehat & .215 & .188 & .215 & 1.144 & .263 \\
\hline
\end{tabular}

a. DependentVariable: Efektif

Sumber: Hasil perhitungan menggunakan SPSS

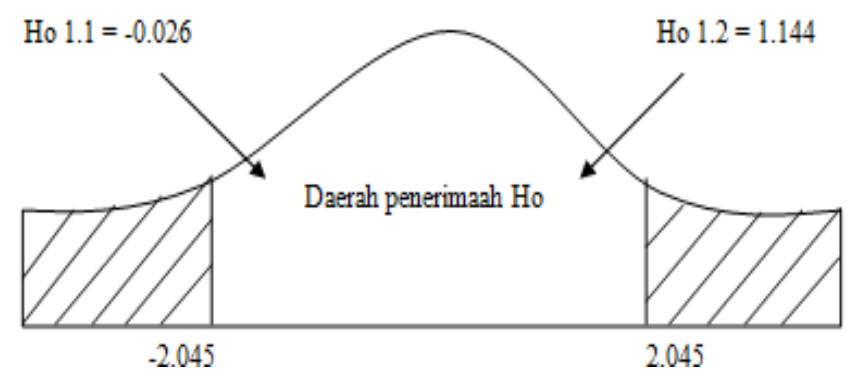

Jika $\mathrm{t}_{\text {hitung }}<\mathrm{t}_{\text {tabel }}$ maka Ho diterima, jika $\mathrm{t}_{\text {hitung }}>$ $t_{\text {tabel }}$ maka Ha diterima. Pada tabel diatas dapat dilihat bahwa $t_{\text {hitung }}$ aman dan sehat $<t_{\text {tabel }}$ maka Ho diterima artinya tidak ada pengaruh antara aman dan sehat 
terhadap efektif. Pada grafik diatas dapat dilihat nilai $t_{\text {hitung }}$ berada pada daerah penerimaan Ho. Pada uraian diatas dapat disimpulkan bahwa tidak ada pengaruh antara mudah terjatuh apabila menaruh benda diatas meja (aman) dan Lecet pada lengan karena tepi meja yang tidak rata (sehat) terhadap Permukaan meja yang sempit/kecil (efektif).

Uji regresi liner meja bahan dasar limbah ban mobil

\begin{tabular}{|c|c|c|c|c|c|c|}
\hline \multicolumn{7}{|c|}{ ANOVA $^{2}$} \\
\hline \multicolumn{2}{|c|}{ Model } & Sum of Squares & $\mathrm{Df}$ & Mean Square & $\mathrm{F}$ & Sig. \\
\hline \multirow{3}{*}{1} & Regression & 4.167 & 2 & 2.083 & & $\therefore$ \\
\hline & Residual & .000 & 27 & .000 & & \\
\hline & Total & 4.167 & 29 & & & \\
\hline \multicolumn{7}{|c|}{ a. Dependent Variable: Efektif } \\
\hline \multicolumn{7}{|c|}{ b. Predictors: (Constant), Sehat, Aman } \\
\hline \multicolumn{7}{|c|}{ Sumber: Hasil perhitungan menggunakan SPSS } \\
\hline \multicolumn{7}{|c|}{ Coefficients $^{2}$} \\
\hline \multirow{2}{*}{\multicolumn{2}{|c|}{ Model }} & \multicolumn{2}{|c|}{ Unstandardized Coefficients } & Standardized & \multirow[t]{2}{*}{$\mathrm{T}$} & \multirow[t]{2}{*}{ Sig. } \\
\hline & & $B$ & Std. Error & Beta & & \\
\hline \multirow{3}{*}{1} & (Constant) & .000 & .000 & & & \\
\hline & Aman & .000 & .000 & .000 & & \\
\hline & Sehat & 1.000 & .000 & 1.000 & & \\
\hline
\end{tabular}

a. DependentVariable: Efektif

Sumber: Hasil perhitungan menggunakan SPSS

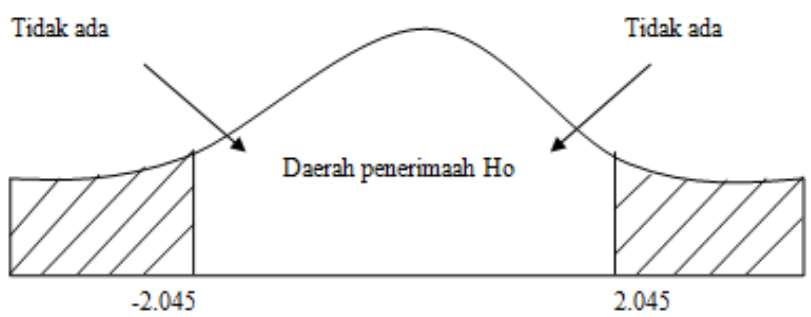

Jika $t_{\text {hitung }}<t_{\text {tabel }}$ maka Ho diterima, jika $t_{\text {hitung }}>$ $\mathrm{t}_{\text {tabel }}$ maka Ha diterima. Pada tabel diatas dapat dilihat bahwa $t_{\text {hitung }}$ aman dan sehat $<\mathrm{t}_{\text {tabel }}$ maka Ho diterima artinya tidak ada pengaruh antara aman dan sehat terhadap efektif. Pada grafik diatas dapat dilihat nilai $t_{\text {hitung }}$ tidak ada maka berada pada daerah penerimaan Ho. Pada uraian diatas dapat disimpulkan bahwa tidak ada pengaruh antara mudah terjatuh apabila menaruh benda diatas meja (aman) dan Lecet pada lengan karena tepi meja yang tidak rata (sehat) terhadap Permukaan meja yang sempit/kecil (efektif).

\section{Uji regresi linier berganda sofa biasa}

\begin{tabular}{|c|c|c|c|c|c|c|}
\hline \multicolumn{7}{|c|}{ ANOVA $^{2}$} \\
\hline Mod & & Sum of Squares & $d f$ & Mean Square & $\mathrm{F}$ & Sig. \\
\hline \multirow{3}{*}{1} & Regression & .296 & 2 & .148 & .717 & $.45^{\circ}$ \\
\hline & Residual & 5.571 & 27 & .206 & & \\
\hline & Total & 5.867 & 29 & & & \\
\hline
\end{tabular}

a. Dependent Variable: Efektif

b. Predictors: (Constant), Efisien2, Efisien1

Sumber: Hasil perhitungan menggunakan SPSS

Coefficients

\begin{tabular}{|c|c|c|c|c|c|c|}
\hline \multirow{2}{*}{\multicolumn{2}{|c|}{ Model }} & \multicolumn{2}{|c|}{ Unstandardized Coefficients } & \multirow{2}{*}{$\begin{array}{c}\begin{array}{c}\text { Standardized } \\
\text { Coefficients }\end{array} \\
\text { Beta }\end{array}$} & \multirow[t]{2}{*}{$\mathrm{T}$} & \multirow[t]{2}{*}{ Sig. } \\
\hline & & B & Std. Error & & & \\
\hline \multirow{3}{*}{1} & (Constant) & 1.495 & .439 & & 3.403 & .002 \\
\hline & Efisien1 & -.096 & .183 & -099 & -.524 & .605 \\
\hline & Efisien2 & .227 & .198 & .217 & 1.145 & .262 \\
\hline
\end{tabular}

a. Dependent Variable: Efektif

Sumber : Hasil perhitungan menggunakan SPSS

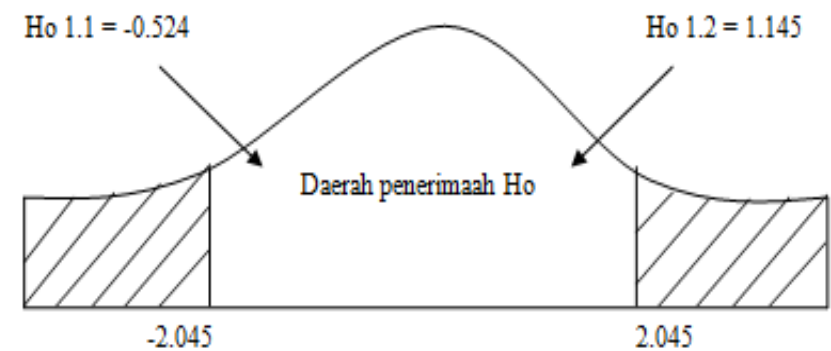

Jika $t_{\text {hitung }}<\mathrm{t}_{\text {tabel }}$ maka Ho diterima, jika $t_{\text {hitung }}>$

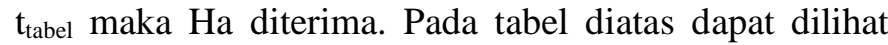
bahwa $t_{\text {hitung }}$ efisien 1 dan efisien $2>t_{\text {tabel }}$ maka Ho diterima artinya Tidak ada pengaruh antara efisien 1 dan efisien 2 terhadap efektif. Pada grafik diatas dapat dilihat nilai $t_{\text {hitung }}$ berada pada daerah penerimaan Ho. Pada uraian diatas dapat disimpulkan bahwa tidak ada pengaruh antara Penggunaan bahan baku meja sudah sesuai (efisien 1) dan meja terlalu banyak memakan ruang (efisien 2) terhadap Permukaan meja yang sempit/kecil (efektif).

Uji regresi linier berganda sofa bahan dasar limbah ban mobil

\begin{tabular}{|l|r|r|r|l|l|}
\hline \multicolumn{1}{|l|}{ MNOdel $^{2}$} & Sum of Squares & Df & Mean Square & F & Sig. \\
\hline Regression & .343 & 2 & .172 & 1.213 & $.313^{\circ}$ \\
$1 \quad$ Residual & 3.823 & 27 & .142 & & \\
\multicolumn{1}{|l}{ Total } & 4.167 & 29 & & & \\
\hline
\end{tabular}
a. DependentVariable: Efektif
b. Predictors: (Constant), Efisien2, Efisien1

Sumber: Hasil perhitungan menggunakan SPSS 
Coefficients $^{2}$

\begin{tabular}{|c|c|c|c|c|c|c|}
\hline \multirow{2}{*}{\multicolumn{2}{|c|}{ Model }} & \multicolumn{2}{|c|}{ Unstandardized Coefficients } & \multirow{2}{*}{$\begin{array}{c}\begin{array}{c}\text { Standardized } \\
\text { Coefficients }\end{array} \\
\text { Beta } \\
\end{array}$} & \multirow[t]{2}{*}{$T$} & \multirow[t]{2}{*}{ Sig. } \\
\hline & & $B$ & Std. Error & & & \\
\hline \multirow{3}{*}{1} & (Constant) & 2.512 & 1.013 & & 2.480 & .020 \\
\hline & Efisien1 & .274 & .185 & .274 & 1.483 & .150 \\
\hline & Efisien2 & .070 & .203 & .064 & .344 & .734 \\
\hline
\end{tabular}

a. Dependent Variable: Efektif Sumber: Hasil perhitungan menggunakan SPSS

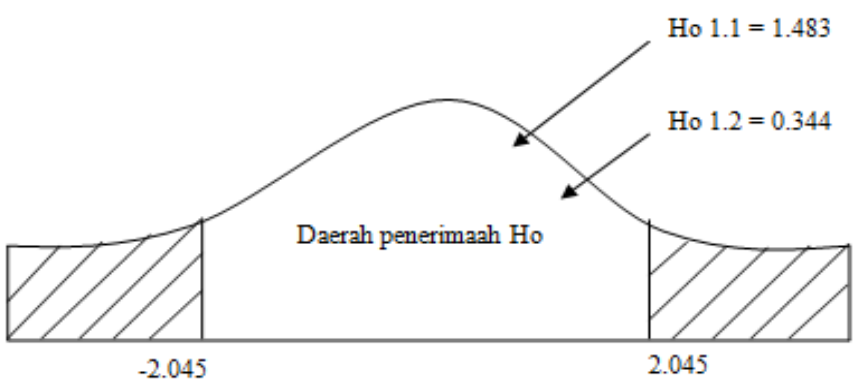

Jika $t_{\text {hitung }}<\mathrm{t}_{\text {tabel }}$ maka Ho diterima, jika $t_{\text {hitung }}>$ $\mathrm{t}_{\text {tabel }}$ maka Ha diterima. Pada tabel diatas dapat dilihat bahwa $t_{\text {hitung }}$ efisien 1 dan efisien $2<\mathrm{t}_{\text {tabel }}$ maka Ho diterima artinya Tidak ada pengaruh antara efektif dan aman terhadap sehat secara simultan. Pada grafik diatas dapat dilihat nilai $t_{\text {hitung }}$ berada pada daerah penerimaan Ho. Pada uraian diatas dapat disimpulkan bahwa tidak ada pengaruh antara Penggunaan bahan baku meja sudah sesuai (efisien 1) dan meja terlalu banyak memakan ruang (efisien 2) terhadap Permukaan meja yang sempit/kecil (efektif).

\section{SIMPULAN}

a. Hasil uji perbandingan dengan menggunakan data kuesioner ENASE meja dan sofa biasa dengan meja dan sofa bahan dasar limbah ban mobil bahwa terjadi perbedaan yang signifikan pada penggunaannya.

b. Hasil uji regresi linier dengan menggunakan data kuesioner ENASE yang dinyatakan valid bahwa tidak ada pengaruh antara variabel dependen dan independen.

\section{DAFTAR PUSTAKA}

Basriyanta. 2007. Memanen Sampah. Yogyakarta: Kanisius.

Bogdan dan Taylor, 1975 dalam J. Moleong, Lexy. 1989.Metodologi Penelitian Kualitatif. Bandung: Remadja Karya

Bridger, R.S. Ph.D. 1995 Introduction to Ergonomics. McGraw-Hill, Inc.

Damara, Doni. 2018. Analisis Meja Belajar Lipat Yang Ergonomis Untuk Anak-Anak Menggunakan Pendekatan Anthropometri. STITEKNAS: Jambi

Chaffin. 1983. Occopation Biomechanics, John Willey $\&$ Sons.

Djaali. 2008. Psikologi Pendidikan. Jakarta: Bumi Aksara.
Falaah, Asron. F. dkk. 2013. Pemanfaatan hasil Pirolisis Limbah Ban bekas sebagai bahan pelunak untuk pembuatan barang jadi Karet: Bogor.

Ghozali, Imam. 2009. "Aplikasi Analisis Multivariate dengan Program SPSS “.

Semarang : UNDIP.

Ginting, R. 2010. Perancangan Produk. Yogyakarta: Graha Ilmu.

Haryono, Suyudi. 2009. Kursi yang baik. Institut Seni Indonesia

Kurniawan, D. 2008. Regresi Linier. Austria: ISBN.

Lismana, Hendri.P.L. dkk. 2013. Kurma mini BABE (Kursi dan meja mini berbahan dasar Ban bekas) dengan Seni motif aneka kartun anak. Fakultas Teknik. Universitas Trunojoyo Madura(UTM).

Dr.M.B.A. Riduwan. 2013. Skala Pengukuran VariabelVariabel Penelitian. Bandung : Alfabeta.

Misbahuddin dan Iqbal Hasan. 2013. Analisis Dara Penelitian dengan Statistik. Edisi Kedua. Bumi Aksara: Jakarta

Nurmianto, Eko. 1991 Ergonomi Konsep Dasar Dan Aplikasinya. Prima Printing, Surabaya.

Prasetyowibowo, Bagas. 1999. Desain Produk Industri. Yayasan Delapan Sepuluh: Bandung

Putra, Endi. 2017. Perancangan meja Laptop Portable yang Ergonomis untuk penyandang Cerebral Palsy pendekatan Antropometri. STITEKNAS: Jambi.

Ramadhan, M. 2019. Perancangan Meja dan Sofa yang Ergonomis dari Limbah Ban Mobil dengan Pendekatan Anthropometri. STITEKNAS: Jambi.

Satwiko. 2009. Pengertian Kenyamanan Dalam Suatu Bangunan. Yogyakarta: Wignjosoebroto.

Sekaran, Uma. (2011). Research Methods for business Edisi I and 2. Jakarta: Salemba Empat.

Steers, Richard. M. 1980. Efektifitas Kerja Definisi Faktor Yang Mempengaruhi dan Alat Ukur Efektifitas Kerja.

Sugiyono. 2014. Metode Penelitian Pendidikan Pendekatan Kuantitatif, Kualitatif dan R\&D. Bandung: Alfabeta.

Sujarweni, V. Wiratna. 2014. SPSS untuk penelitian. Yogyakarta: Pustaka Baru Press.

Sutarto. 1978. Efektifitas Kerja Definisi Faktor Yang Mempengaruhi dan Alat Ukur Efektifitas Kerja. 